\title{
Dermatomyositis Skin Severity Index
}

National Cancer Institute

\section{Source}

National Cancer Institute. Dermatomyositis Skin Severity Index. NCI Thesaurus. Code C121363.

An assessment of disease activity in the skin of patients with dermatomyositis. 